\title{
Результаты первичной интродукции и особенности развития видов рода Paeonia L. (сем. Paeoniaceae Rudolphi) в Полярно-альпийском ботаническом саду
}

\section{The results of the primary introduction and particularity of development of the species of genus Paeonia L. (Paeoniaceae Rudolphi) in the Polar-alpine botanical garden}

\author{
Вирачева Л. Л., Ворсина А. А. \\ Viracheva L. L., Vorsina A. A. \\ Полярно-альпийский ботанический сад-институт имени Н. А. Аврорина, г. Апатиты, Россия. \\ E-mail: viracheva-ljubov@yandex.ru
}

Avrorin Polar Alpine Botanical Garden-Institute, Apatity, Russia

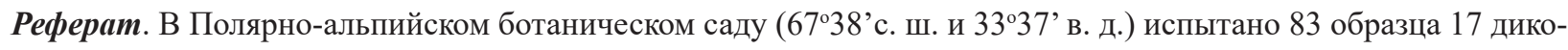
растущих видов рода Paeonia L. B настоящее время в коллекции содержатся 12 видов (24 образца). В результате проведенных исследований было установлено, что большинство изученных видов рода Paеопіа успевают пройти полный цикл сезонного развития в условиях Заполярья. Ритм сезонного развития видов рода Раеопіа зависит от погодных условий и экологических условий произрастания растений в естественных фитоценозах. Изученные виды рода Раеопіа обладают высокой декоративностью в течение всего вегетационного сезона. Все растения зимуют без укрытия, неприхотливы, не требуют специальных приемов культивирования.
\end{abstract}

Ключевые слова. Интродукция, Мурманская область, род Раеопіа L., сезонное развитие, фенология.

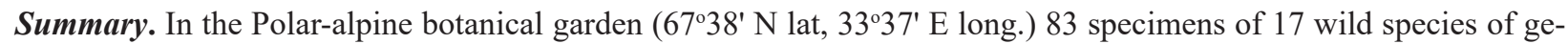
nus Paeonia L. have been tested. Now the collection contains 12 species (24 samples). As a result of the research it was found that most of the studied species of genus Paeonia have time to go through the full cycle of seasonal development in the Arctic. The rhythm of seasonal development of species of genus Paeonia depends on the weather and ecological conditions of plant growth in natural phytocenoses. The studied species of the Paeonia genus possess a high degree of decorativeness throughout the growing season. All plants overwinter without shelter, unpretentious; do not require special cultivation techniques.

Key words. Introduction, genus Paeonia L., Murmansk Region, phenology, seasonal development.

Научная деятельность лаборатории интродукции растений Полярно-альпийского ботанического сада (ПАБСИ) направлена на создание коллекций, изучение особенностей видов, размножение растений и сохранение в условиях культуры. Одна из задач интродукции - разработка ассортимента растений, пригодных для озеленения городов Заполярья. Для этих целей привлекаются декоративные растения, способные украсить улицы северных городов, такие, как виды рода Paeonia L.

Род Рaеопia - единственный род семейства Paeoniaceae Rudolphi - состоит из 40 видов, являющихся травянистыми многолетниками и кустарниками и распространенных в основном в Европе и Азии, два вида произрастают в Северной Америке (Головкин и др., 1986). Во «Флоре СССР» приводятся 15 видов (Шипчинский,1937). На территории Мурманской области встречается 1 вид - Paeonia anomala L. (Орлова, 1956). В культуре пионы выращивают с древних времен.

История интродукции рода Paеопіа в Полярно-альпийском ботаническом саду началась в 1932 г. с введения в культуру Paeonia anomala и Paeonia lactiflora Pall. 
На коллекционном питомнике Полярно-альпийского ботанического сада, в центральной части Кольского полуострова $\left(67^{\circ} 38^{\prime}\right.$ с. ш. и $33^{\circ} 37^{\prime}$ в. д.), расположенном в садово-парковой части на высоте 340 м над ур. м. в зоне редкостойной северной тайги, испытано 83 образца 17 дикорастущих видов рода Paeonia. Растения выращиваются в открытом грунте и в полной мере испытывают на себе воздействие специфических природно-климатических условий Кольской Субарктики (Алисов и др., 1954), значительно отличающихся от природных условий их естественного произрастания.

1. Paeonia anomala L. - пион марьин корень. Негустые леса, опушки, лесные и приречные луга, кустарники и каменистые склоны таежной и севера широколиственнолесной зоны, в горах до альпийского пояса европейской части СССР, Сибири, Средней Азии, Монголии и Северного Китая.

2. Paeonia caucasica (Schipcz.) Schipcz. - пион кавказский. Леса и лесные опушки, лесные поляны и луговины, кустарниковые заросли лесной зоны от предгорий до субальпийского пояса (900-2000 м) Кавказа. Эндем.

3. Paeonia daurica Andr. - пион даурский. Леса и открытые склоны горно-лесного пояса Крыма и Запалного Предкавказья. Эндем.

4. Paeonia delavayi Franch. - пион Делавея. Сухие сосновые или дубовые леса, заросли, реже травянистые склоны или поляны в еловых лесах от горнолесного до альпийского пояса гор Восточной Азии и Юго-Западного Китая.

5. Paeonia hybrida Pall. - пион степной. Степные луга, заросли кустарников, открытые травянистые и каменистые склоны холмов и сопок на равнинах и в нижнегорном поясе Западной Сибири, Средней Азии, Северного Китая.

6. Paeonia lactiflora Pall. - пион молочноцветковый. Сухие, каменистые склоны, луга, кустарники, опушки, берега рек таежной и широколиственнолесной зон, в горах в горнолесном поясе и горных степях Дальнего Востока, востока Монголии, Китая, Японии.

7. Paeonia macrophylla (Albov) Lomak. - пион крупнолистный. Горные леса (800-1000 м) Кавказа (Аджария). Эндем

8. Paeonia mascula (L.) Mill. - пион мужской. Лиственные леса, кустарники, в горах до горно-лесного пояса субтропической зоны Средиземноморья (Южная Европа, Западные Балканы, Румыния, Греция, Италия, Северо-Западная Африка, Крым и Малая Азия).

9. Paeonia mlokosewitschii Lomak. - пион Млокосевича. Скалы и открытые склоны лесной зоны Кавказа. Редкий эндемик Лагодехского заповедника.

10. Paeonia obovata Maxim. - пион обратнояйцевидный. Смешанные и лиственные дубовые и березовые леса от юга таежной до широколиственнолесной зоны, в горах до субальпийского пояса Дальнего Востока, Китая, п-ова Кореи, Японии.

11. Paeonia officinalis L. - пион аптечный. Светлые, сухие скалистые склоны широколиственнолесной и средиземноморской зон, в горах в горно-лесном поясе Европы и Малой Азии. Кроме основного вида, испытана разновидность Paeonia officinalis L. ssp. Microcarpa Nyman.

12. Paeonia oreogeton S. Moore - пион горный. Хвойно-широколиственные и лиственные леса, склоны сопок или в тенистые леса вдоль рек Дальнего Востока, Китая и Японии.

13. Paeonia peregrina Mill. - пион иноземный. Под пологом светлых дубовых лесов, зарослей светолюбивых кустарников в предгорьях Южной Европы (от Испании до Балканского п-ова) и Малой Азии.

14. Paeonia steveniana Kem.-Nath. - пион Стевена. Леса, опушки, кустарники от верхнего лесного до субальпийского пояса Кавказа. Эндем горной Колхиды.

15. Paeonia tenuifolia L. - пион узколистный. Степи, степные склоны, кустарники и опушки степной зоны Ср. Европы, европейской части СССР, Предкавказья, Балкан и Малой Азии.

16. Paeonia veitchii Lynch - пион Вича. Кустарники, песчаные и глинистые места, леса, опушки от горно-лесного до альпийского пояса гор Северного, Центрального и Юго-Запдного Китая. Кроме основного вида, испытана разновидность Paeonia veitchii Lynch var. woodvordii (Stern \& Cox) Stern.

17. Paeonia wittmanniana Hartwiss ex Lindl. - пион Виттмана. Горные леса, лесные опушки и поляны, кустарники от горно-лесного до субальпийского пояса гор Закавказья, Северо-Восточной Турции и Ирана. 
Исходный семенной материал был получен из зарубежных и отечественных ботанических садов в порядке обмена, ряд видов были привезены живыми растениями из экспедиционных поездок сотрудников сада или из других организаций.

При семенном размножении семена высевали в теплице в ящики с земельной смесью обычно в март-апреле. Посеянные семена всходят через 1-2 года. Молодые растения высаживаются в открытый грунт, где они в дальнейшем растут и зимуют без укрытия. Цветение этих растений начинается через 5-10 лет. Растения же, привезенные из экспедиций, как правило, сразу высаживаются в открытый грунт и цветут уже через 1-3 года. На протяжении всего периода выращивания за растениями осуществлялся регулярный уход, заключающийся в подкормке минеральными удобрениями, известковании почвы, подсыпке земли на гряды, прополке, делении и пересадке растений по мере разрастания.

Фенологические наблюдения проводили по методике, принятой в ПАБСИ, каждые 2-3 дня в течение всего вегетационного периода (Бейдеман, 1954; Методика ..., 1979). Фиксировали следующие сроки прохождения фенологических фаз: начало вегетации, бутонизации, цветения, и плодоношения. Фенологическая фаза считалась наступившей, если она фиксировалась хотя бы у одного растения.

Для определения успешности интродукции растений использовали методику, разработанную Б. Н. Головкиным (1973). Баллы приживаемости подсчитывались в соответствии с 12-бальной шкалой:

1 - растения существовали в вегетативном состоянии только в год высадки на питомник (или появления всходов - при грунтовом посеве в открытом грунте);

2 - растения существовали в вегетативном состоянии не менее двух лет, т.е. у них отмечена, по крайней мере, одна удачная перезимовка;

3 - у растений цветение наблюдалось однажды; после цветения они не перезимовали, т.е. вели себя как монокарпики;

4 - цветение было отмечено единично, однако растения после цветения существовали в течение нескольких лет;

5 - у растений цветение и плодоношение наблюдались только один раз;

6 - растения нерегулярно цвели, но не плодоносили;

7 - растения нерегулярно цвели, плодоношение было отмечено только однажды;

8 - растения нерегулярно цвели и плодоносили;

9 - растения ежегодно цвели, но не плодоносили;

10 - растения цвели ежегодно, плодоношение отмечено только однажды;

11 - растения ежегодно цвели, плодоносили нерегулярно;

12 - растения цвели и плодоносили ежегодно;

Периодичность цветения и плодоношения определялась с года первого цветения растений, которые находились в испытании не менее семи лет.

В настоящее время в коллекции содержатся 24 образца 12 видов пионов. Результаты интродукционного испытания пионов в Полярно-альпийском ботаническом саду приведены в таблице (табл.).

Наблюдения показали, что самый высокий средний балл приживаемости имеет $P$. anomala $(7,1)$. Для P. mascula средний балл приживаемости не подсчитывали, поскольку цветение и плодоношение растений наблюдалось в течение пяти лет.

Три вида растений - P. macrophylla, P. mlokosewitschii, P. steveniana - существовали в условиях Кольского полуострова только 3 года и не успели достичь имматурного состояния (средний балл приживаемости 1-2). Два вида - P. caucasica и P. daurica - цветут периодически, но из-за поздних сроков цветения семена не успевают вызревать (средний балл приживаемости 4-6). P. delavayi за все время испытаний цвел лишь однажды (средний балл приживаемости 2,7).

Большинство видов современной коллекции рода Paeonia успевают пройти полный цикл сезонного развития в условиях Заполярья. Группа растений, достигающих фазы плодоношения очень неоднородна:

- растения, способные ежегодно цвести и плодоносить: P. anomala, P. officinalis (до 12 баллов, в среднем 4,1-7,1);

- растения ежегодно цветут, но плодоносят нерегурярно: P. oreogeton, P. veitchii (до 11 баллов, в среднем 3,8-11); 
- растения цветут и плодоносят периодически: P. mascula, P. obovata, P. peregrina, P. tenuifolia, P. wittmanniana (до 8 баллов, в среднем 4,5-6,2);

- растения периодически цветут, но плодоношение наблюдалось только однажды: P. hybrida, P. lactiflora (до 7 баллов, в среднем 3,3-3,4).

Отсутствие или нерегулярность плодоношения объясняется климатическими условиями в пункте интродукции, в частности, более коротким периодом вегетации, а также экологическими условиями произрастания растений в естественных ценозах.

По данным Г. Н. Андреева и Г. А. Зуевой (1990), Paeonia anomala отличается способностью к натурализации. Для этого вида характерно наличие самовоспроизводящегося самосева и устойчивого клонового потомства в условиях питомников и в искусственных (культурных) фитоценозах.

Таблица

Результаты интродукции видов рода Paeonia L. на Кольском полуострове

\begin{tabular}{|c|c|c|c|c|c|}
\hline \multirow[b]{2}{*}{ Виды } & \multirow{2}{*}{$\begin{array}{c}\text { Годы } \\
\text { испытания }\end{array}$} & \multicolumn{2}{|c|}{ Количество образцов } & \multirow{2}{*}{$\begin{array}{c}\text { Конечная } \\
\text { фаза } \\
\text { развития }\end{array}$} & \multirow{2}{*}{$\begin{array}{c}\text { Баллы } \\
\text { приживаемости }\end{array}$} \\
\hline & & $\begin{array}{c}\text { прошедших } \\
\text { испытание }\end{array}$ & $\begin{array}{c}\text { имеющихся } \\
\text { в } 2017 \text { г. }\end{array}$ & & \\
\hline P. anomala & 1932-по н.в. & 24 & 8 & $\Pi$ & 7,1 \\
\hline P. caucasica & 1977-по н.в. & 1 & 1 & Ц & 6 \\
\hline P. daurica & 1948-1994 & 3 & $-*$ & Ц & 4 \\
\hline P. delavayi & 1979-по н.в. & 3 & 1 & Ц & 2,7 \\
\hline P. hybrida & 1957-1998 & 6 & $-*$ & $\Pi$ & 3,3 \\
\hline P. lactiflora & 1932-по н.в. & 8 & 4 & $\Pi$ & 3,4 \\
\hline P. macrophylla & 1977-1979 & 1 & $-*$ & $\mathrm{~B}$ & 1 \\
\hline P. mascula & 2005-по н.в. & 1 & 1 & $\Pi$ & $-* *$ \\
\hline P. mlokosewitschii & 1977-1982 & 1 & $-^{*}$ & $\mathrm{~B}$ & 2 \\
\hline P. obovata & 1947-по н.в. & 6 & 1 & $\Pi$ & 6,2 \\
\hline P. officinalis & 1939-по н.в. & 5 & 1 & $\Pi$ & 4,1 \\
\hline P. oreogeton & 1955-по н.в. & 2 & 2 & $\Pi$ & 11 \\
\hline P. peregrina & 1939-по н.в. & 4 & 2 & $\Pi$ & 4,5 \\
\hline P. steveniana & $1977-1981$ & 1 & $-*$ & $\mathrm{~B}$ & 2 \\
\hline P. tenuifolia & 1938-по н.в. & 6 & 1 & $\Pi$ & 4,3 \\
\hline P. veitchii & 1947-по н.в. & 8 & 1 & $\Pi$ & 3,8 \\
\hline P. wittmanniana & 1955-по н.в. & 3 & 1 & $\Pi$ & 3,7 \\
\hline
\end{tabular}

Примечание: В - вегетация; Ц - цветение; П - плодоношение; «-*» - в настоящее время отсутствует в коллекции; «-**»- цветет менее 7 лет

На основании изложенных фактов можно сделать следующие выводы:

1. Большинство изученных видов рода Раеопіа успевают пройти полный цикл сезонного развития в условиях Заполярья.

2. Ритм сезонного развития видов рода Paeоnia зависит от погодных условий и экологических условий произрастания растений в естественных фитоценозах.

3. Изученные виды рода Paeonia обладают высокой декоративностью в течение всего вегетационного сезона.

4. Все растения зимуют без укрытия, неприхотливы, не требуют специальных приемов культивирования.

\section{ЛИТЕРАТУРА}

Алисов Б. П., Берлин И. А., Михель В. М. Курс климатологии. - Ч. 3. - Л.: Гидрометеоиздат, 1954. - 320 с.

Андреев $\Gamma$. Н., Зуева Г. А. Натурализация интродуцированных растений на Кольском Севере. - Апатиты, 1990. $-122 \mathrm{c}$. 
Бейдеман И. Н. Методика фенологических наблюдений при геоботанических исследованиях. - М.-Л.: изд-во АН CCCP, 1954. - 130 c.

Головкин Б. Н. Переселение травянистых многолетников на Полярный Север. - Л., 1973. - 266 с.

Головкин Б. Н., Китаева Л. А., Немченко Э. П. Декоративные растения СССР. - М.: Мысль, 1986. - 328 с. Методика фенологических наблюдений в ботанических садах СССР // Бюл. Гл. ботан. сада, 1979. - Вып. 113. - C. 3-8.

Орлова Н. И. Пионовые - Paeoniaceae (DC.) Bartl. // Флора Мурманской области. - Т. 3. - М.-Л.: Изд-во АН CCCP, 1956. - С. 259-260.

Шипчинский Н. В. Пион - Раеопіа L. // Флора СССР. - Т. 7. - М.-Л., Изд-во АН СССР, 1937. - С. $24-35$. 